\title{
The Impact of the Belt and Road Initiative in Boosting Local Business through Asia and Africa Satisfaction: A Study of Kenya-China Business Projects
}

\author{
Mister Alkhalloufi Toumert \\ The Faculty of Business and Accountancy, Lincoln University College, Kualau Lumpur, Malaysia \\ Email: toumert.alkhalloufi@icloud.com
}

How to cite this paper: Toumert, M. A. (2021). The Impact of the Belt and Road Initiative in Boosting Local Business through Asia and Africa Satisfaction: A Study of Kenya-China Business Projects. Open Journal of Business and Management, 9, 17141742.

https://doi.org/10.4236/ojbm.2021.94094

Received: May 7, 2021

Accepted: July 12, 2021

Published: July 15, 2021

Copyright $\odot 2021$ by author(s) and Scientific Research Publishing Inc. This work is licensed under the Creative Commons Attribution International License (CC BY 4.0).

http://creativecommons.org/licenses/by/4.0/

\begin{abstract}
The core idea of the BRI is to create peace and cooperation between nations, acceptance and inclusive assistance, mutual learning platform, and mutual benefit for states actors and citizens. It is also one of its pillars to achieve shared growth through debate and collaboration. This study wanted to answer the questions on the economic reach of the B \& R, its capacity to fill in the gap in foreign investment towards developing nations, the fulfillment of its economic mission, and the challenges it faces. Among the chosen population of this study, samples were acquired using simple random sampling, which will answer the survey questionnaire. The survey results showed that the majority of the respondents were from China, with International Relations studies and diplomats based in Beijing. The results showed that the B \& $\mathrm{R}$ initiative has proven to be a key economic initiative with a domestic impact and an international one. It has ignited a new economic momentum for undeveloped economies eager to have access to funds and know-how in Infrastructure building, highways, airports, seaports, railway linkages, and energy development have an impact on the social and local economic fabrics of the host nations. The data and survey results all point to the initial success of the B \& R initiative. As the COVID-19 has halted the world economic flow, the future is still undecided on how China will pursue its globalization through the Belt and Road while strengthening its domestic GDP to overcome the global economic turndown.
\end{abstract}

\section{Keywords}

B \& R Initiative, Impact, Boosting Local Business, Asia and Africa Satisfaction 


\section{Introduction}

\subsection{Background of the Study}

The Belt and Road Initiative has sparked much interest and high-profile economic meetings and international media attention (Capital on The Road: Belt and Road Boosts Yuan Worldwide, 2018). In this study of the B \& R, as a first objective, the researcher tried to answer a specific context of its implementation, the business side of the initiative, especially its impact on Infrastructure growth and business development in Asia and Africa. A secondary objective was to understand the different financial and institutional tools China has established to realize business projects within the $\mathrm{B} \& \mathrm{R}$ initiative. The third objective was to review the academic and business research on the $\mathrm{B} \& \mathrm{R}$ initiative. The fourth was to take a case study of Kenya to see further the real impact and actual projects affecting the nation's beneficiary of the $B \& R$, the monetary consequences on local economies, and the connectivity role of the $\mathrm{B} \& \mathrm{R}$ in linking regional economies to China. Finally, we discuss the challenges that the $\mathrm{B} \& \mathrm{R}$ faces regarding financing projects, getting around geopolitical considerations, local acceptance, and the COVID-19 impact on the initiative.

Introduction to the $\mathrm{B} \& \mathrm{R}$

Chinese President Xi Jinping went to Central and Southeast Asia in September and October 2013 to unveil the Belt and Road Initiative-China's plan to develop a Silk Road Economic Belt and a 21st Century Maritime Silk Road in collaboration with related countries (What is Belt and Road Initiative, 2020). Via a consultative process and collaborative initiatives, the initiative promotes policy cooperation, infrastructure and facility connectivity, free trade, financial integration, and closer people-to-people relations (Ponomarenko et al., 2017).

The core idea of the BRI is to create peace and cooperation between nations, acceptance and inclusive assistance, mutual learning platform, and mutual benefit for states actors and citizens. It is also one of its pillars to achieve shared growth through debate and collaboration. This theory suggests that discussion can bring great thinkers together to find better solutions to various problems while working together allows all parties in the BRI to play to their strengths. The guiding thought is to share growth and benefit more people (The Belt and Road Initiative: From China, For The World, 2019).

President Xi Jinping has proposed that if the Belt and Road are being built to economically soaring Asia, connectivity is the wings' arteries and veins. Connectivity through the BRI is to bring together the building of infrastructure, develop more robust regulations, and promote more personnel exchanges. It has to support policy discussion, infrastructure connectivity, International free flow trade, investment opportunity funds availability, and finally, people-to-people exchanges (The Belt and Road Initiative. From China, For The World, 2019).

The project is divided into two parts. The first is the land-based "Silk Road Economic Belt," which links China to Central Asia, Eastern Europe, and West- 
ern Europe. Next is the "21st Century Maritime Silk Road," a sea-based project (Phillip, 2020). It is thought to connect China's southern coast with the Mediterranean, Africa, Southeast Asia, and Central Asia. Since the "Belt" is a road network and the "Way" is a sea path, the names are confusing (Seth, 2021).

The Economic Importance of the Belt and Road Initiative and Potential Impact

In our modern context, there are several virtual channels to achieving this more excellent financial connectivity.

The Increased Capital Mobility which freely enables capital to flow even more, and the Increased Financial Inclusion (Lagarde, 2019).

The B \& R can, with more than 120 nations and institutions, provide a solid medium for business development to developing countries. The fact is that today these nations only receive around $2 \%$ of foreign investment. Most of their citizens do not have access to banking, thus financing. This is the B \& R opportunity to bring micro-financing, E-commerce tools to facilitate connectivity between sellers and buyers and build an affordable infrastructure to complete the logistic gaps in these nations.

\subsection{Research Questions and Objectives}

This research is exploratory, and it attempted to discover different perspectives, subjective perceptions around the belt and road initiative.

Specifically, this sought answers to the following:

1) What is the economic reach of the $B \& R$ ?

2) Will the $B \& R$ fill in the gap in foreign investment towards developing nations?

3) How will B \& R fulfill its economic mission?

4) What are the challenges facing the $B \& R$ initiative?

As per the research objective, as cited in the study background, the paper tried to give a new fresh outlook into the B \& R initiative results since 2013 .

For this objective, this paper identified the following:

1) The economic impact on the nation's signatory of the initiative.

2) The financial institutions that support the $B \& R$ initiative.

3) A successful case study that shows the B \& R in action.

4) The economic and geopolitical challenges that can limit the B \& R global engagement.

\subsection{Research Goals and Significance}

The research focuses on the B \& R initiative's economic impact in South Asia and Africa, the institutions established to promote the project and inject finances into the economies concerned by the B \& R. The paper will look at Kenya as a sample of study of the Belt and Road initiative's success and challenges to fill in the gap of economic investment in developing nations. Also, it is the objective of the research to offer an academic study of the B \& R, its geopolitical reach, actual 
results, and its future.

\subsection{Scope and Limitation of the Study}

The research will focus on South Asia and Africa's economic reach of the B \& R initiative, taking Kenya as a sample to see the B \& $\mathrm{R}$ achievements and challenges. In this paper, some considerations will also be studied concerning the institutions managing the project and the geopolitical environment in which the $\mathrm{B}$ \& R operates. However, the study itself will not cover the implications of the B \& $\mathrm{R}$ initiative in Europe and South Asia, nor focus on the political and economic actors that have not decided to join the project and the reason for their refusal to do so.

\subsection{Organization of the Thesis}

How has the B \& R initiative influenced the economic relation between China and its South Asian neighbors and African supporters?

The study tries to highlight the economic impact of China B \& R on South Asia and Africa, and for that purpose, the research will be decided as follows. In the second chapter, we will review the B \& R economic impact since 2013, the leading nations and agencies signatory of the initiative, the institutions created to support the project, and some reflections put forward by economists and diplomats on the B \& R project. In the second chapter, we will also introduce Kenya as a case study nation to see the impact of $B \& R$ and the challenges that it faces. Chapter three will enable us to understand the research design and methodology. It discusses the research method and the research process. Chapter four will be dedicated to providing analytical data from primary and secondary surveys dealing with the B \& $\mathrm{R}$ chapter one issues. Chapter five will focus on giving your own opinion on the research and summarize the study from an economic and academic perspective.

\section{Literature Review}

\subsection{The Economic Significance of the Belt and Road for China}

In the article written by Toumert Alkhalloufi (2019), the Belt and Road Initiative (BRI) has been widely watched worldwide since 2013. The concept began with creating a platform and financial mechanisms to integrate developing countries into China's quest for a more unified economic strategy and to construct muchneeded infrastructure that developing countries require to join the fifth industrial revolution and participate in the twenty-first-century financial framework. It is considered the primary driver of infrastructure development in a region struggling to close the disparity between its economic potential and the realities of its inadequate infrastructure (Alkhalloufi, 2019).

According to the World Bank, South Asia will need to invest roughly $\$ 2$ trillion in infrastructure between 2011 and 2020 if it wants to be a part of the new economic order that will shape the future (Alkhalloufi, 2019). This is precisely 
what China's policymakers are proposing to South Asian countries via the BRI. A look at the projects that have been completed so far reveals how China's foreign development initiatives are aligned with the UN's objective. From Sri Lanka to the Maldives to Pakistan, the projects already demonstrate the initiative's tangible results.

Bangladesh's Padma bridge will connect 21 southern districts with the capital. Sri Lanka's Colombo Port City project is an important step forward in the BRI. The \$1.4 billion port, co-developed with China, establishes itself as a vital economic center for local and regional trade and connectivity (Alkhalloufi, 2019).

Finally, we may point to Pakistan's Gwadar Port, part of the China-Pakistan Economic Corridor (CPEC), as a significant achievement in regional integration and a model for other regions to study and comprehend its economic vision. The BRI has accomplished its fundamental meaning: regional development and international integration, with more than $\$ 50$ billion invested in the project. It's a comprehensive infrastructure corridor with a deep-sea port, motorways, and airports to help move products, services, and people between these countries more quickly and safely (Alkhalloufi, 2019).

The BRI is not just a regional project, as its global status and inclusive nature indicate. Africa can be seen as a significant benefactor of China's economic efforts to aid the continent's development and help its infrastructure and economy meet its growth targets.

The signed Memorandum of Understanding (MOU) of collaboration between China and 37 African countries and the African Union in 2018 could be regarded as a watershed moment for the BRI in Africa. Between 2012 and 2016, China provided an average of $\$ 11.5$ billion in infrastructure financing to Africa. China-backed projects are the $\$ 5.8$ billion Mambilla Hydropower Plant in Nigeria, the Addis Ababa-Djibouti railway, the $\$ 11$ billion port in Bagamoyo, Tanzania Nairobi-Mombasa railway project (Alkhalloufi, 2019). The Suez Canal corridor in Egypt is another project that is moving forward and may have similar ramifications to CPEC in South Asia. Chinese investors are expected to contribute more capacity to the Egyptian economy through the signing of a BRI MOU, connecting it to the rest of Africa and the Middle East. All of these accomplishments have been centered on the global macro-economy, but there is another binding effect that research and the media have overlooked, and it has the potential to improve the lives of countless people. We must extend our perspective to include linkages between cities and local businesses rather than just between state actors.

People and small enterprises have become the BRI's stakeholders, which go beyond the conventional institutional participants in international development. Thanks to decreasing shipping and transportation costs via sea lines, railways, highways, global mobility networks, and access to previously inaccessible hubs, the globe is approaching a new era of equal market access. However, the most important aspect of the BRI is that it did not define itself by challenging ideas or 
objectives (Alkhalloufi, 2019).

OBOR is of vital significance to China as it aims to push its domestic economic GDP to a new height and is also a part of the nation's plan for economic diplomacy. By linking the less-developed provinces like Xinjiang with neighboring countries, China expects to increase its economic value to the national GDP. OBOR is anticipated to open and expand Chinese goods and industries (China's One Belt and One Road Initiative (OBOR), 2018). It would also allow the manufacturing powerhouse to take command of cost-effective avenues for easily exporting materials (Seth, 2020).

The $\mathrm{B} \& \mathrm{R}$ is an internal drive to the Chinese economy first. Taking the route from the traditional Silk Road that started in Xian to link North China to its southwest border, and ease communication, transportation, and the movement of goods internally, the new initiative is somehow a copy of the ancient trade route.

According to $\mathrm{Yu}$ (2016), economic and strategic, and historical factors are the motives behind the Project. Lower growth rates and the decline of the domestic GDP are key factors for OBOR and new foreign policies (Yu, 2016). Due to lower local consumption, higher labor costs, and an aging population, which result in higher social costs, China is trapped in a domestic economic slowdown Figure 1 (Zhao, 2016). The B \& R regarding the New Silk Roads is essential (Zhao, 2016).

Another consequence or objective of the B \& $\mathrm{R}$ initiative is The Chinese government's recent reforms and policies to improve the position of the RMB on the global financial market (Nabar \& Tovar, 2017).

According to Nabar and Tovar (2017), the internationalization of the currency takes time. However, the use of RMB in international trade will increase its financial and monetary systems worldwide.

As Cheng (2016) and Du (2016) discussed, the New Silk Roads will encourage RMB on the global scene, which can be a step closer to the currency's internationalization. Reforms and policies connected to the internationalization of RMB

GDP in China 1978-2015

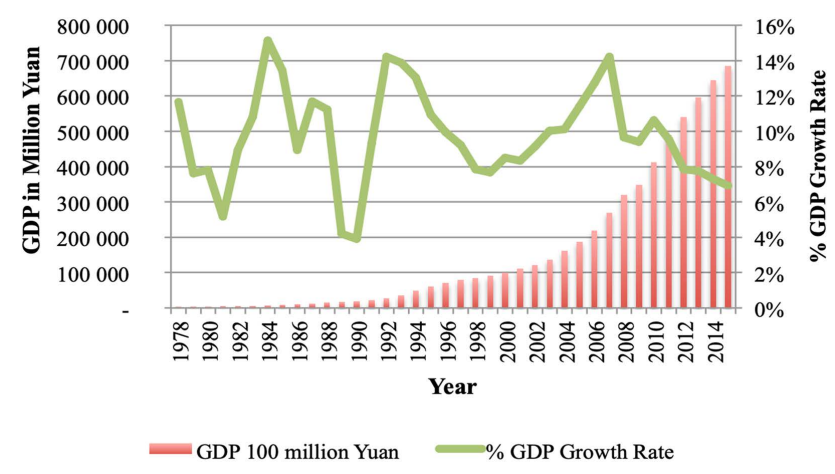

Data are presented in 2015 prices. Source: The World Bank, 2017a.

Figure 1. China GDP growth from 1978 to 2015. 
will also support and encourage sustainable growth within the country (Nabar \& Tovar, 2017).

China has been trying since 2010 to position itself as a leader of a new economic order, a driver of the fifth industrial revolution. However, that cannot happen if two major economic re-design do not follow:

- Giving time to old economic infrastructure time to switch, thus the B \& R role in providing room to export and phase out some products and production to nations in need.

- Creating new economic ventures based on A.I., robotic e-commerce, and logistics. Able to produce internally, export to the world added value product and finally control the logistic routes and means either hard assets such as ports and airports, or cyber through business giants such as Alibaba.

The B \& R initiative is supported by a significant financial commitment and platform. According to PwC's calculations, B \& $\mathrm{R}$ will be able to get up to $\$ 1$ trillion in outbound state funding from the Chinese government over the next ten years. The majority of this investment will be made in the form of a preferential loan, with some stock included. The government has established special vehicles to distribute this money to the most relevant projects and activities. These include, for example, the creation of the New Silk Road Fund (NSRF), the Asian Infrastructure Investment Bank (AIIB), and the government directing vast sums of its foreign exchange reserves and some of its major state-owned enterprises to the region.

B \& R implementation, if carried out at full size, will last 30 - 40 years. Because it will be the 100th anniversary of the formation of the People's Republic of China, 2049 is a watershed event (China's New Silk Route: The Long and Winding Road, 2016).

The Chinese government hopes to counter domestic overcapacity by exporting its well-developed engineering and construction capabilities, materials and equipment, and self-developed technologies through the B \& R project. Apart from China's experience in constructing world-class infrastructure, it will primarily transport excess capacity at a low opportunity cost, so there is no need for speedy returns. At the same time, China intends to increase demand for its goods and services by improving connectivity and trade between Asia, Europe, and Africa, resulting in medium- and long-term growth momentum and an increase in GDP (China's New Silk Route: The Long and Winding Road, 2016).

Around 16 of China's 27 provinces are covered by B \& R, and an even more significant number have expressed an interest in participating. The project provides a clear opportunity for several less-developed regions, primarily in rural China, to catch up with the more sophisticated provinces on China's East coast. By improving connections with neighboring areas, the central government hopes to provide more stability to the interior states (most notably Xinjiang).

$\mathrm{B} \& \mathrm{R}$ is also China's broad strategy for assuming a more prominent leadership role on the world scene and strengthening connections with its neighbors in 
its current form. China seeks to increase its influence in a geopolitical marketplace where global powers compete for influence in emerging economies (China's New Silk Route: The Long and Winding Road, 2016). With a strategy that appears primarily centered on loans and aid, the country intends to help China grow its financial power (including the wider international usage of its currency) alongside its trade power.

The economic impact is also to be seen through the nations and population coverage of the B \& R initiative Figure 2.

The Belt and Road Initiative encompasses $1 / 3$ of global trade and GDP and more than $60 \%$ of the worldwide population (Belt \& Road Initiative (BRI), 2019).

The B \& R itself has six economic corridors:

1) The New Eurasian Land Bridge, which connects Western China to Western Russia.

2) The China-Mongolia-Russia Corridor, which borders North China to Eastern Russia via Mongolia.

3) The China-Central Asia-West Asia Corridor, which links Western China to Turkey via Central and West Asia.

4) The China-Indochina Peninsula Corridor, which connects Southern China to Singapore via Indo-China.

5) The China-Pakistan Corridor, which connects South Western China through Pakistan to Arabia sea routes.

6) The Bangladesh-China-India-Myanmar Corridor connects Southern China to India via Bangladesh and Myanmar (Seth, 2020).

There are 138 nations involved in the Belt and Road Initiative (List of Belt \& Road Member Countries, n.d.) (Figure 3).

- 38 countries are in Sub-Saharan Africa

- 34 BRI countries are in Europe \& Central Asia (including 18 countries of the European Union (E.U.) that are part of the BRI)

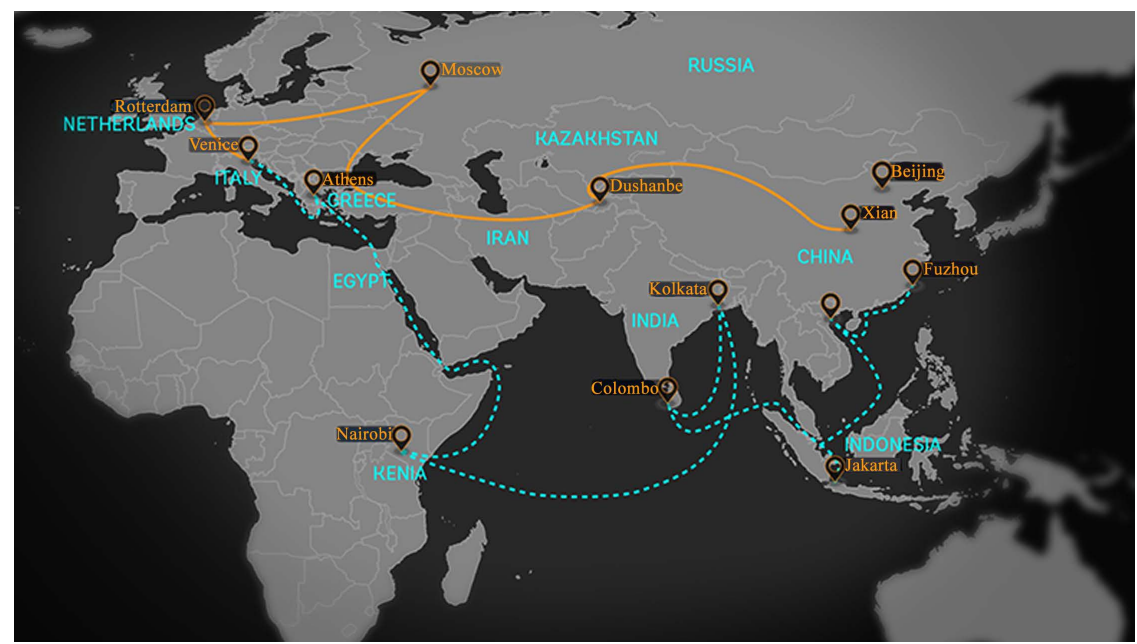

Figure 2. World bank map. 


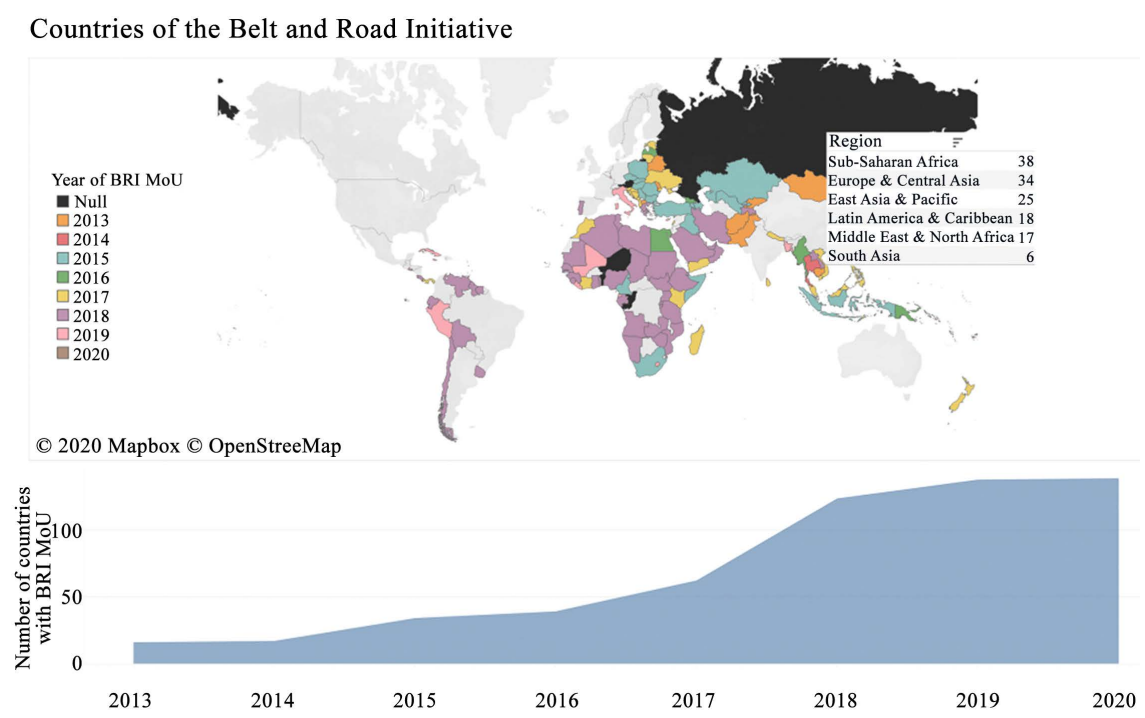

Figure 3. Nations of the B \& R.

- 25 BRI countries are in East Asia \& pacific

- 17 BRI countries in the Middle East \& North Africa

- 18 BRI countries are in Latin America \& the Caribbean

- 6 countries are in SouthEast Asia

From the nations involved and the corridors, we can also understand the economic reach of these economies through research on their actual percentage impact on global trade.

The World Bank research paper shows the linear evolution of trade patterns of B \& R Economies using the U.N. Comtrade database, which covers bilateral trade of 182 economies in total.

It is to note that the database only contains product-level information, informing us only on gross trade flows of intermediate and final goods. The U.N. Comtrade database has the most significant country coverage of all the databases at disposal for scrutiny. For 182 countries, it covers all bilateral gross trade figures. These are exports and imports of final and intermediate goods that are recorded by customs agencies. The first fact is that the portion of B \& $\mathrm{R}$ Economies in world trade has been increasing over time.

In Figure 4, we observe that in 2015 the share of the 63 B \& R Economies in world exports (i.e., exports of the 182 economies covered in the database) is $37 \%$, and their importance in world exports has been growing since 1995 when their share was $21 \%$.

Figure 5 further suggests that this has been mainly driven by exports of intermediate goods, of which the share of B \& R Economies proliferated more than that of final goods, reflecting an increase in Global Value Chains participation. $B$ \& R Economies also have a relatively larger share of intermediate goods exports, accounting for $42 \%$ of total middle exports (Table 1, Figure 2, panel A), compared with 24\% for the share of final goods in Figure 6 (Table 2, Figure 2, panel B) (World Bank Report May 2018). 


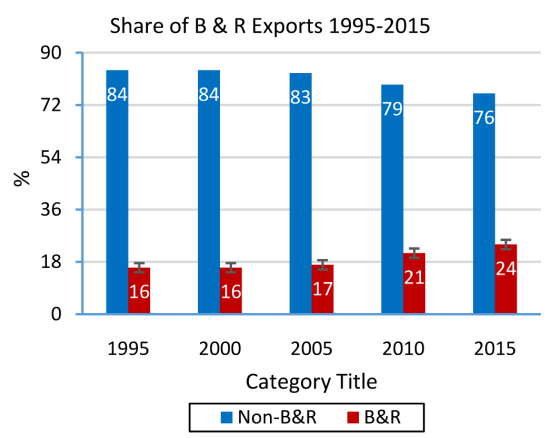

Figure 4. Share of B \& R export numbers.

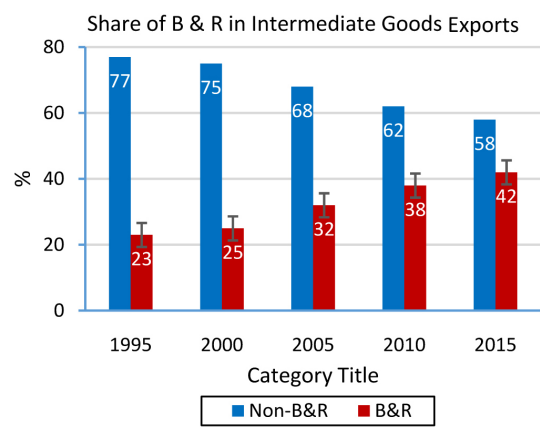

Figure 5. Intermediate goods export.

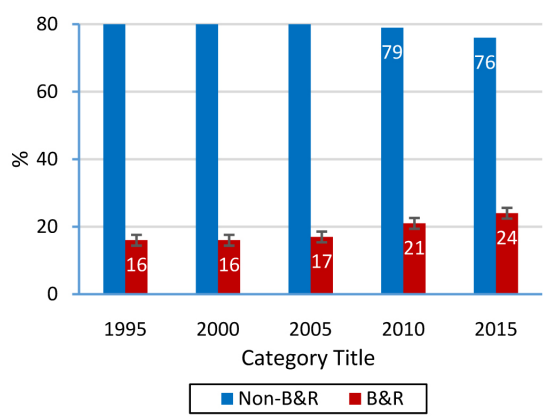

Figure 6. Final goods export.

Table 1. Employment position.

\begin{tabular}{cc}
\hline Work Position & Percentage \\
\hline Student & $29 \%$ \\
Teacher & $14 \%$ \\
General Worker & $7 \%$ \\
Ambassy & $7 \%$ \\
Manager & $7 \%$ \\
Diplomat & $7 \%$ \\
Researcher & $7 \%$ \\
Employee & $7 \%$ \\
Regional Manager & $7 \%$ \\
International Import and Export Trade & $7 \%$
\end{tabular}


Table 2. Country of origin.

\begin{tabular}{cc}
\hline Country & Percentage \\
\hline China & $86 \%$ \\
Morocco & $7 \%$ \\
Gabon & $7 \%$ \\
\hline
\end{tabular}

\subsection{The Foreign Policy Aspect of the Belt and Road Initiative}

The B \& R initiative changed China's view of the world in the years that followed the historical opening up towards the market economy. In 1979, China's objective from the B \& $\mathrm{R}$ is to engage the international system through its platform. In fact, for many decades, the country focused on realizing reforms to prepare the society to enter a globalized world.

This view was crucial to reach the high-level economic results that have made China one of the most powerful states globally and have increased the living standards of its citizens. But now the situation has changed, and the Chinese leaders have understood that they had to make a new strategy to face its unique economic situation and the world.

This new opening will require a more internationally proactive China that focuses on technology and know-how export rather than the traditional import since 1979 (Kratz, 2015).

The Belt and Road are trying to complement the international economic order, not to create a new one, a community of shared destiny starting in Asia, as said by President Xi (Godement, 2015).

By recreating old Silk Road connections across Eurasia, the South China Sea, the Middle East, and East Africa, the B \& R program aims to build connectivity, a structured logistic chain linking China and its primary focus areas. However, the Belt and Road Initiative is not merely a re-enactment of the past. This is a vision of China under Xi Jinping's leadership, with a well-developed governance system. An ideology that repositions China where it has always belonged: as a powerful nation with a significant impact on the advancement of human civilization (Alkhalloufi, 2017).

China has been developing its ability to lead the world economically since the late 1980s. Being the world's second-largest economy was not achieved by accident or unforeseen circumstances. It takes a clear goal, a well-executed strategy, as well as patience and milestones, not just hard effort. Xi has a clear vision and plans to help China integrate into the global economy and merge China's drive. The world is a complicated environment with sophisticated processes, and China considers bringing countries together, getting people to understand others, and bringing economies together to complement each other to be a big task.

China's ambition for the Belt and Road initiative is to bring security, peace, cooperation, and prosperity to the world by incorporating diverse core interests into the initiative to make national and international players aware of the possi- 
bilities of a shared Chinese dream. These considerations compel us to wonder why China, rather than the United States, Russia, or Europe, should bear the burden of this vision. Indeed, I'd want to use the phrase mandate, but not from heaven, but from the poorer half of the world's population, whose combined wealth equals that of the world's 62 wealthiest billionaires (Alkhalloufi, 2017).

China is a modern state gracefully assimilated into the new world to help Chinese residents move from poverty to prosperity. For the past 70 years, China has demonstrated a new route for humanity and governance in terms of its commitment to the well-being of its population and the equitable distribution of wealth and prosperity.

Today, everyone is asking for Chinese visitors to spend their money in their nations, for Chinese businesses to invest in their countries, and even for China to take the lead in solidifying global order gains. To put it another way, the world's forgotten citizens have given $\mathrm{Xi}$ a mandate to improve their chances of realizing the Chinese dream by establishing the B \& R project. Finally, I'd like to dig more into the Belt and Road initiative's philosophy. We cannot and should not reduce the industry to a commercial corridor. The $\mathrm{B} \& \mathrm{R}$ project is far more than that; it is China's way of conveying its fundamental ideological and cultural cornerstones to the rest of the world.

Humanity is progressing quickly now, the world is constantly changing, and new governance paradigms are being searched.

The goal of the B \& R initiative is to have a significant impact on the local populace. Railways, roads, docks, and shipping lines are all designed to win the hearts and minds of the general public by providing the infrastructure required to participate in a global local world. It is not the goal of the project to construct infrastructure. Some say that it has a far broader meaning: it promotes hope and opportunity without bias. The Belt and Road Initiative serves a higher purpose, driving civilization toward a brighter future through a Chinese dream (Alkhalloufi, 2017).

\section{How Chinese Academics and Economists View the Belt and Road?}

How Diplomats, Media Professional and International Economists View the Belt and Road?

\section{Main Financial Institutions that Support the Belt and Road Initiatives}

At first look, China's Belt and Road Initiative (BRI) and the Asian Infrastructure Investment Bank (AIIB) appear to be two hands attached to the same body. However, this has not been the case. This misunderstanding, on the other hand, is easily forgiven. Both the BRI and the AIIB were established in the same year by the same government leadership with the same purpose: to increase infrastructure and, by extension, economic connectedness throughout Asia, as Frontera News' Remy Stuart-Haentjens recently noted out (Shepard, 2017).

When China launched the AIIB in October 2013, it was widely believed that it would serve as the financing arm for many of the country's newfound international infrastructure building ventures, as well as a competitor to the established 
guard of multilateral development banks, such as the World Bank, ADB, and EBRD. However, facts began to emerge that demonstrated beyond a shadow of a doubt that extra investment for Asian infrastructure development was desperately needed. Asia's infrastructure needs are expected to be over $\$ 22.6$ trillion by 2030 , according to estimates. The difficulty is that, while the World Bank, Asian Development Bank, and European Bank for Reconstruction and Development are all quite active in Asia, their total production is insufficient. These expensive projects are often too costly and dangerous for the private sector or any single government to undertake (Shepard, 2017).

The AIIB quickly became evident that it wasn't just a Chinese "we want one, too" project, but something desperately required-and the world community stepped forward to help. Today's AIIB has 80 members, with 20 of them being either European or broadly allied with European policy. Typically, these include stalwart US allies such as the United Kingdom, France, and Germany.

Many European countries realized that joining the AIIB was not only a practical step toward the building of much-needed infrastructure, but it was also the only chance to have a real say in its direction. It was initially believed that the AIIB would act as a rival to the more established multilateral development banks, undercutting them with weaker environmental and social standards to gain a foothold in Asia's infrastructure development arena. A critical mass of European countries jumped in and ensured the adoption of environmental, social, and energy norms that were basically copied and pasted from the World Bank and ADB, effectively suffocating this potential.

Although China continues to have the most weighted voting power in the AIIB, this does not mean that the Bank is fundamentally Chinese-controlledthere have been instances where other members have usurped China's say in the development of the Bank's Articles of Agreement. With the ongoing admission of new members, it has even been suggested that China's veto power may soon be lost.

Azerbaijan, India, Bangladesh, Pakistan, Myanmar, Tajikistan, Indonesia, Oman, and Georgia are among the nations where the AIIB has advanced 16 projects totaling $\$ 2.5$ billion. Before the end of the year, the value of this investment is estimated to reach $\$ 4$ billion (Shepard, 2017).

The AIIB and the B \& R Initiative will, in the end, have tremendous synergy and will undoubtedly cross paths at numerous vital crossings. Aside from direct finance for some BRI or BRI-related projects, the AIIB's present investments in power plants and transportation infrastructure will benefit multiple BRI projectsand vice versa. This information, however, should not be taken out of context since the BRI overlaps with many of the World Bank's, Asian Development Bank's, and EBRD's large infrastructure projects. The World Bank funded the Kazakhstan section of the Western Europe-Western China Highway, which will run from China's Yellow Sea to Russia's Baltic Sea and serve as the BRI's core corridor's main thoroughfare. 
Many of the big multilateral banks' development projects, as well as government initiatives like China's Belt and Road Initiative, Japan's JICA and Japan Infrastructure Initiative, India's North-South Transport Corridor, and similar projects spearheaded by Russia, can be seen as parts of the same effort to develop, interconnect, and economically fortify the massive swath of the world that stretches from east to west. This is what the New Silk Road entails, and it will undoubtedly go down in history as the world's largest development project (Shepard, 2017).

\section{About AIIB}

The Asian Infrastructure Investment Bank (AIIB) aims to improve Asia's social and economic conditions. We started operations in January 2016 in Beijing and already have 103 approved members all over the world. We can better connect people, services, and markets throughout Asia and beyond by investing in sustainable infrastructure and other productive industries, which will have a long-term impact on billions of people and help to build a brighter future (Saki, 2018).

Financing Operations

The Bank will "give or facilitate financing to any member, or any agency, instrumentality, or political subdivision thereof, or any organization operating in the territory of a member, as well as to international or regional agencies or entities involved with the economic development of the Asia area," according to the AIIB's Articles of Agreement (AOA). Furthermore, the AOA allows the Bank to offer financing in various ways, including providing loans, investing in an enterprise's equity capital, and guaranteeing loans for economic development in whole or in part, whether as a primary or secondary obligor. In addition, for purposes compatible with its mission, the Bank may underwrite or participate in the underwriting of securities issued by any organization or enterprise.

Sovereign-Backed Financing

Sovereign-backed financing is a guarantee that:

1) "covers debt service defaults under a loan that are caused by a Government's failure to meet a specific obligation about the Project or by a borrower's inability to make a payment under the loan" (Financing Operations, n.d.)

2) "is accompanied by a Member Indemnity" (Financing Operations, n.d.)

Non-Sovereign-Backed Financing

Non-Sovereign-backed financing refers to any funding provided by the Bank that is not backed. It includes any funding provided to or for the benefit of a private firm or a sub-sovereign body (such as a political or administrative subdivision of a Member or a public sector firm) that is not supported by a guarantee or counter-guarantee and indemnity supplied by the Member to the Bank ( Financing Operations, n.d.).

Equity Investment

The Bank can make direct equity investments in both private and public firms. It has the option of investing in either a new or established business. The in- 
vestment could come in various forms, such as Subscriptions to common stock or preferred stock (or a mixture of the two); A debt can be converted into equity. The Bank's investment cannot exceed thirty percent (30\%) of the company's total assets (Financing Operations, n.d.).

However, in rare circumstances, the Board may accept a higher but non-controlling share; if the Bank's investment is jeopardized, the Bank may take control of the company to protect its investment (Financing Operations, n.d.).

Preparation Advances for Sovereign-Backed Financing

The Bank may elect to advance (Preparation Advance) to fund preparatory work for a project funded by sovereign debt. A Preparation Advance is only given when there is a good chance that the funding for the project will be extended; nonetheless, offering a Preparation Advance does not require the Bank to finance or otherwise support the project for which it is given. For any given project, the total principal amount of all approved Preparation Advances cannot exceed the lesser of: The President decides whether to authorize each Preparation Advance or ten percent (10\%) of the project's overall expected amount of finance USD10 million equivalent (Financing Operations, n.d.).

\subsection{Kenya, a Case Study of the Belt and Road Initiative}

Africa with Kenya, a case study of the Belt and Road Initiative African strategy in place (Marcel, 2018). In the past decade, China has been extensively working towards the economic growth of the African continent. And now, under president xi jinging's B \& R initiative, it will invest about 60 billion US dollars. China is building infrastructure all across the globe.

Both the Kenyan government and China companies have made a massive investment in Kenya for the past 10 years. Today, the country is far ahead in looking at China as an example for its own development. You can already notice this across many sectors like business, education, and social initiative.

To explore behind the economic headlines in Nairobi. And to see China's globalization in action. China's government is definitely investing a lot of time and money in Africa, but regardless of the outcome, they are gaining enormous amounts of actual influence across the continent. There are two significant numbers to consider. China only loaned $\$ 12$ billion to African countries in 2015. The government only put $\$ 3$ billion into Africa (Marcel, 2018).

China's growing influence on the continent is because the Chinese government no longer has to push it. China's private business is encroaching on Africa. Rather than the numerous Chinese state-run corporations, $90 \%$ of the estimated 10,000 Chinese enterprises in Africa are privately owned (Sinha, 2020).

As Chinese small businesses grip the continent, several individuals and forces are pushing the effort forward. Much of the western world is neglecting Africa's prospects, dismissing the fact that doing business in Africa can now be as successful as it was when China's time of rapid expansion began. Africa is currently establishing itself as a labor and resource supplier for China. Africa will continue 
on its path toward becoming China's China unless the west pays attention.

At the China-Africa meeting in Marrakech, the potential created by new Chinese silk routes and Beijing's industry relocation policies spurred promises of investment and prosperity. More than 400 businesses, including 150 Chinese, attended the inauguration of the two-day summit. China has risen to become Africa's most important economic partner in less than two decades. According to figures released during the meeting, their commerce reached $\$ 190$ billion in 2016 and is now more significant than the continent's total commerce with India, France, and the United States. Following Kenya, Ethiopia, Egypt, and Djibouti, Morocco has joined the "New Silk Roads" initiative, which calls for roads, ports, railway lines, and industrial parks constructions in 65 nations for a total cost of over $\$ 1$ billion (Marcel, 2018).

This infrastructure development, known as China's "Belt and Road," involves a land belt connecting the world's second-largest economy to Western Europe via Central Asia and Russia and a sea connection to Africa. Europe is bordered on two sides by the China Sea and the Indian Ocean. This industrial transfer, according to Ivorian Minister Brou, is a "wonderful chance" for Africa. China was the first foreign investor in Africa in 2016, committing $\$ 36.1$ billion to the continent. According to estimates provided at the summit, Chinese businesses had assisted in the construction of about a hundred industrial parks, thousands of railways and motorways, as well as multiple airports and power plants by the end of that year. East Africa is particularly prosperous, and three countries are at the forefront: Kenya, Ethiopia, and Djibouti. On the spot, ports, railways, and roads are primarily financed by China: 4 billion dollars (3.7 billion Euros) to connect Ethiopia to Djibouti, 13 billion to irrigate Kenya with a mesh More than half of China's planned investment in this new Silk Road will go to Africa. It is mainly the port facilities that are concerned. The encirclement of the continent by a dozen ports financed by China thus corresponds to this "belt" evoked by Beijing. $90 \%$ of Africa's imports and exports go through the sea. Durban in South Africa and Port Said in Egypt being the two largest container ports on the African continent, it was essential to offer other ports of entry into the African continent.

Kenya, an Open Door to Africa

Kenya is currently one of the largest economic partners in China, which has already invested a lot and assisted in realizing many projects, including infrastructure. A few days before his departure for China, Uhuru Kenyatta thought it worthwhile to remember all this: "As the Kenyans know very well, our country has dramatically benefited from Chinese investment, especially in infrastructure. The roads and transmission lines".

Indeed, the B \& $\mathrm{R}$ has opened a new chapter in cooperation between China and Kenya, said a Chinese diplomat. Guo Ce, an economic and trade adviser at the Chinese Embassy in Kenya, said in an editorial in a local daily newspaper, The Standard, that a new chapter in China-Kenya cooperation has opened as 
soon as Kenyan President Uhuru Kenyatta's visit to Beijing for the International Cooperation Forum of the New Silk Road, where he was the only African President. In terms of cooperation, the Chinese official noted that the two friendly countries have pursued together with the "spirit of peace and cooperation, openness and inclusiveness, mutual learning and mutual benefit" (Full Text of President Xis Speech at Opening Of Belt and Road Forum-Xinhua, 2017) specific to the new road Silk. In May, bilateral cooperation between China and Kenya was brought to the stage of global strategic partnership. The two countries' presidents also agreed to continue constructing roads and ports and integrating the Mombasa-Nairobi Normal Channel Railway Project, Mombasa Port Terminal, and Mombasa Special Economic Zone. More Intensive and Enhanced Synergy of Kenya's National Development Strategy with the Belt and Road Initiative (New Silk Road) Will Strengthen Pragmatic Mutual Cooperation, Bringing a Better Future to Common Development and More Concrete Benefits for the people of both countries, he said. The friendship between China and Kenya goes back more than 600 years when Zheng $\mathrm{He}$, a great navigator of the Chinese Ming Dynasty, landed on the east coast of Kenya. Zheng arrived in Malindi and brought back to China a giraffe, which was welcomed as a sign of fortune and kingship because it resembles the creature named "Kylin" in Chinese mythology. Subsequently, Zheng He's fleet made frequent visits to Kenya and other parts of Africa to spread the "blessing of peace" of ancient China. Currently, China is the largest trading partner, the largest supplier, the largest lender, and the largest source of foreign tourism in terms of Kenya's rapid growth.

China has impacted Kenyans infrastructure or has defined infrastructure in Kenya as (Perkins, 2016) Studied that economic infrastructure must be taken as the foundation of a building and said that it plays a principal role in facilitating the multitude of productive economic activities. He also found the correlation between economic growth and infrastructure development (Srinivasu \& P, 2013). Explained that infrastructure investment is a vital conducting force to achieve quickly and sustained economic growth. That said, the infrastructure in terms of transport plays a strategic role in the development process and contributes to growth. In the beginning, the President of Kenya said that the initiative's purpose is to galvanize global cooperation. With a GDP of 63.40 billion dollars and a population of 46 million as of 2015 (World Bank, 2016), Kenya is the entry point for the maritime B \& $\mathrm{R}$ into Africa from Asia. The projects linked to the OBOR initiative could be deciphered through an analysis of documents and news items. The project's main components are the renovation of Mombasa port, the construction of an ultra-modern port in Lamu, and constructing a new standard gauge railway line connecting Mombasa port, Nairobi, and landlocked neighboring nations. The railway and pipeline are envisaged to link the port in Kenya to oil fields in South Sudan and Uganda while joining Ethiopia, Rwanda, Burundi and facilitating export. The railway line is expected to cover $2700 \mathrm{~km}$ with phase I, the 610 kilometer stretch from Mombasa to Nairobi construction 
underway. The cost is estimated to 25 billion US dollars, with China Exim bank being the dominant financier covering $90 \%$ of the price.

Infrastructure plays a significant role in Chinese-Africa union cooperation. In 2015 and 2016, the two parties signed memoranda of understanding (MoUs) on cross-continental infrastructure development, including railways, highways, aviation, and the high-speed train network. In Kenya, the most noticeable impact is on the infrastructure front, with an estimated foreign direct capital investment of USD 25 billion on the railway modernization, a pipeline from Kenya to South Sudan paying USD 4 billion. In contrast, Lamu port and associated infrastructure investment will be USD 27 billion when complete (daily nation, March 6, 2016). This is capital that Kenya as a country cannot raise, but the B \& R and its associated financial institutions can come in and bridge the deficit. When fully operational, these projects will benefit oil exports from Uganda and South Sudan, whose conflict with Sudan has led to challenges on exporting her oil to China and other countries. At the height of successful oil production by Sudan before the conflict, and retained 75\%. With conflict still persisting, investment in Sudanese oil is not bearing fruits as optimum production of oil has not been attained. Therefore, the Kenyan route offers an opportunity for South Sudan to export oil to China without being frustrated by the north, a win-win situation for South Sudan and China. In the same breath, the discovery of oil through Kenya, as she is landlocked. With the Kenyan route secure, China has also taken care of any prospects for future $\mathrm{B} \& \mathrm{R}$ expansion into the African hinterland while getting a strategic port for call in the event of any security challenge in the horn of Africa region.

Chinese are also aiding Nairobi with a commitment for the road infrastructure sector, estimated at around $\$ 500$ million. In this area, China ranks third after the World Bank and the African Development Bank, ahead of the European Union. In Nairobi, several roads are currently under construction or have been built by the Chinese. Project management by Chinese donors can be examined against the methods of other bilateral donors such as the European Union or Japan. It presents several differences. The speed of completion of the projects and the lower level of costs are systematically underlined. They are explained first by a shorter project cycle. While the European Union finalizes a road in about ten years between identifying the Project and its operational delivery, the Chinese do not exceed four years. The preparatory phases are conducted much more quickly.

On the European side, the identification, the formulation, the validation, and the award of a contract can last about six years, whereas six months are enough for China. This difference is partly due to the shortcomings of the studies carried out by Chinese companies, while environmental impact studies and detailed plans are carried out by independent consulting firms before a construction contract is awarded for any European project. On the Chinese side, the practice is precisely the opposite: studies are often conducted internally by the company 
holding the contract after attribution. The Chinese tradition of tied aid, characterized by the absence of international tenders, makes it possible to avoid lengthy procedures and launch projects more quickly 4 . Second, the lack of a social approach to projects helps to shorten deadlines. While the Europeans or the Japanese, for example, set up compensations for the inhabitants displaced by the projects, the Chinese are criticized for the expulsions they undertake. The Kenyan government reportedly allowed Chinese companies to do their job and even occasionally provide security 5 . This agreement enables the authorities to blame the Chinese while saving the cost of relocation of the inhabitants. Finally, the rate of supervision by Chinese managers concerning the local workforce is more significant than in Western companies. In fact, one more hierarchical level is occupied by expatriate executives in Chinese companies, up to the level of work leader. This increased local presence promotes better control of deadlines.

The B \& R outcome of one Belt One Road in the Kenyan economy is seen through an accelerated GDP in 2016 to $6.0 \%$, after 5.6\% in 2015. In 2015 the outcome of one belt one road in terms of world export was 37\%, up from $21 \%$ in 1995. Worldwide, the performance of B \& $\mathrm{R}$ in the period of good export is $42 \%$ which is very strong. Kenyan activity has been supported by the tourism sector, which is gradually recovering from the plummeting crowds following the terrorist attacks of 2013 and 2015, by the energy and construction sectors, and finally by agriculture, which benefited from favorable past weather conditions. The external situation improved in 2016 for both exogenous and domestic reasons. The current account deficit rose from $6.8 \%$ to $5.5 \%$ of GDP. This improvement is primarily due to the lightening of the oil bill (due to low international oil prices) and the relative weakness of imports of capital goods (due to delays in deploying infrastructure projects).

The reserves reached USD 7.8 billion at the end of 2016, or approximately 4.8 months of imports. The improvement in the external accounts has allowed the Kenyan shilling to depreciate slightly throughout the year 2016. The latter lost $1.4 \%$ of its value against the dollar throughout the year, a lower level than the depreciation of $10.7 \%$ observed in 2015. In 2015/16, according to the IMF, the public deficit reached $7.8 \%$ of GDP1. Budgetary revenue was lower than expected (19.2\% of GDP compared with $20.4 \%$ forecast) as public spending (27.1\% of GDP against $28.4 \%$ ). The overstatement of public expenditure is mainly due to the limited disbursement of investment expenditure (7.3\% of GDP compared to $8.7 \%$ ) while current expenditure has evolved as expected (19.6\% of GDP compared to $19.5 \%)$. (\%). In perspective, for 2017, growth would suffer from the law of framing rates while the deficits public and current would remain high. The law on the control of interest rates, which came into force in September 2016, sets a ceiling for lending rates of commercial banks at 400 bp above the CBK's key interest rate. Due to the negative impact of this law on bank credit among SMEs in particular, activity should slow down to $5.3 \%$ in 2017. The slowdown in action is also motivated by the drought that hit the first half of the year 2017 in 
Kenya. The current account deficit is expected to slow in 2017, to 5.7\% of GDP: imports of capital goods could resume, thanks to the lifting of uncertainties after the August elections, while exports would benefit a more buoyant international context. Finally, although in decline, the public deficit would remain high at $6.9 \%$ according to the IMF, and $6.0 \%$ according to the local authorities: the current expenditure would not be the object of any adjustment contrary to the expenditure 9-Sino-Kenyan relations with diversified modalities.

A favorable reception frame, in response to the needs generated by development and urbanization, the Kenyan authorities welcome contributions from foreign countries, but not limited to members of the OECD Development Assistance Committee. The so-called emerging donors are an alternative. At the end of the 2002 elections, the governing coalition in power established a strategy policy of openness towards Asian countries, called "Look East Policy" This positioning is based on the principle that Asia, through its development, can contribute to the development of Kenya at a lower cost compared to Western countries. Several agreements have been concluded with China and Japan and Korea in infrastructure, mineral exploration, agriculture, retail trade, etc. The absence of conditions imposed by these countries on policies and reforms also contributes to this orientation of the Kenyan authorities. At the institutional level, the reception of foreign financing is controlled flexibly, according to the partners. Direct investments by foreigners are facilitated by the Investment Promotion Authority, which grants licenses to foreign companies without the obligation of partnership with a local company. In 2012, 67 Chinese companies registered in Kenya, including 25 in the building and construction sector and nine in real estate.

\subsection{The Belt and Road Initiative Challenges}

The B \& R initiative is subject to a variety of operational and strategic challenges. Chinese sources suggest that Beijing is using BRI investments as a tool to stabilize border regions, secure energy supply, and foster a more robust diplomatic and economic relationship with nations taking part in the initiative.

However, those goals can be constrained by broad challenges from the physical risks of operating in remote and unstable areas to the possibility of unilateral and coordinated opposition from other significant economic challenges to China.

We can also add the inherent economic challenges of infrastructure development (such as developing and poorly governed states to repay debts).

Aware of the risks, Beijing provides all forms of domestic power to create a safer and more strategically advantageous context for the BRI. China is developing other solutions plus its PLA, including host nation support, private security firms, law enforcement initiatives, securing $B$ \& $R$ personnel and assets. At the strategic level, Beijing uses high-level engagements, public diplomacy, and economic support to reduce the potential for the BRI to aggravate competition with 
other major powers.

We can also assume China's success will depend in part on the reactions of other countries. From a US perspective, the US administration will have to weigh competing factors as it designs a response: an overt confrontation with Beijing may impose a cost on US firms hoping to take advantage of new opportunities and harm US-China relations, while accommodation could fuel Chinese ambitions, jeopardize US interests in prudent lending and market access, and alienate US partners such as Japan and India that have expressed serious concerns about China's activities. The Department of Defense will also have to consider tradeoffs as it decides whether and how to collaborate with the PLA to enhance security along BRI routes.

Even before the BRI was launched in late 2013, China had experienced the dangers involved in conducting business operations in remote and unstable regions. Major incidents, such as the 2011 Libyan civil war, which required the PLA to complete an improvised evacuation of around 35,000 Chinese oil workers, grabbed domestic headlines and placed an impetus on Beijing to consider how Chinese personnel and assets could be protected. Thus Chinese officials have been under no illusions about the physical risks involved in building infrastructure and transportation networks across conflict-prone areas of Central and South Asia and into the Middle East. Setting public expectations at a realistic level, Xi acknowledged in 2017 that the BRI runs through areas marked by "conflict, turbulence, crisis, and challenge." Although China has thus far avoided significant security incidents along $B \& R$, several recent cases illustrate the potential risks to B \& R workers and projects. These include the March 2015 evacuation of more than 500 Chinese workers and managers from Yemen, creating not only threats to overseas workers, but also regional instability astride key maritime shipping lanes; the November 2015 killing of a Chinese citizen by ISIS radicals in Syria; the May 2017 abduction and murder of two Chinese citizens in Pakistan's Baluchistan province (site of Gwadar Port and another key B \& R project); and a December 2017 Chinese embassy warning that terrorist attacks in Pakistan may be imminent.

Chinese analysts anticipate that these problems will stay as BRI projects enter their construction and operational phases. Key challenges include:

- Inter-and intrastate sectarian violence, which could destabilize host nations, places workers in danger

- Hostage-taking for ransom

- Terrorist attacks

And significant natural disasters such as earthquakes and mudslides may increase due to political risk analysis capabilities.

From an economic standpoint, the world is still wary of accepting the B \& $\mathrm{R}$ and the promise of a Chinese-led economic model as a growth engine for codevelopment. Many intellectuals saw the Anglo-Saxon-EU method as timetested, saying that China's current political system is incompatible with Western 
liberal democratic values and so unviable. Furthermore, the world has recently emerged from a worldwide recession, and there is uncertainty that China will complete the B \& R (Lim \& Mack, 2018).

Even though China has proved that it has the technological capabilities, financial resources, and commitment to complete the B \& R, confidence in China's ability to achieve it is harmed by several significant domestic and international problems, including the United States trade war, EU negotiations for an investment treaty, and a few economic difficulties relating to debt risk (Lim \& Mack, 2018).

\section{China's Domestic Challenges}

There is also the financing issue. Given the scope and scale of the B \& R and its milestones, China's ability to finance the entire Project remains a question. The finance solution can be the stock market.

Another issue is that China's B \& $\mathrm{R}$ approach to global economic concerns may be exaggerated. This is especially concerning because the $B \& R$, once finished, will encompass almost 62.5 percent of the world's population and 65 countries. In other words, this endeavor will affect more than half of the world's social and economic well-being (Lim \& Mack, 2018).

Given that China's B \& R partners would be inextricably linked to China once the program was completed, any ripples in the Chinese economy would almost certainly bounce outwards, both positively and negatively, to the other countries in the network (Lim \& Mack, 2018).

Finally, these issues are not exclusive to China; they affect numerous countries around the world. As a result, for the world to trust China's economic leadership, she must establish the credibility of the B \& R by effectively managing domestic issues and assisting developing countries in their transition to the fourth industrial revolution. Only then would China be able to persuade the rest of the world that the "Chinese Dream" is real (Lim \& Mack, 2018).

\section{Research Methodology}

\subsection{Research Design}

The researcher opted for both qualitative and quantitative through a survey to go ahead in the research. For quantitative hypotheses, the researcher used a set of close-ended questions. While for qualitative hypotheses, the researcher used open-ended questions.

As part of the research, I a did systematic surveys of key constituencies involved in the Belt and Road Initiative and Diplomacy in general.

\section{Population and Sampling}

This study used simple random sampling to acquire respondents with which the survey will be conducted.

The population chosen were:

1) Diplomats

2) Students in the Field of Diplomacy 
3) Journalists

4) Entrepreneurs

The questionnaire was sent via link to around 100 correspondents through Linkdin, Wechat, and e-mails. Notification letter was sent to explain that the questionnaire is a part of a survey for a final thesis.

\subsection{Questionnaire Construction}

The survey developed has ten questions in which each accomplished its objective. The survey is a combination of close-ended questions that look to comprehend the demographic makeup of the respondents, the Belt and Road initiative, and the impact and challenges linked to B \& R. The survey is designed to take less than twenty minutes. The survey was constructed and administered on SurveyMonkey.com.

The Survey was a two page questionnaire with 10 questions in total.

The questions focused on the respondent's experience as a principal, characteristics of their field if study and work, attitudes toward the Belt and Road initiative, and their experience with the project either as direct stakeholder or from an academic prospective.

\subsection{Response Rate}

The survey closed on the principals on January 15th, 2021. 60 applicants answered the survey in total from the 100 submitted, which gives us a rate of $60 \%$.

\subsection{Survey Quality Measures}

All data are of course subject to errors only sample data have sampling error. However, both sample and census data may contain non-sampling error. Nonsampling error can lead to improper conclusions about the data if the errors are not taken into consideration.

\subsubsection{Response Error}

Response error means that the data obtained about a member of the population are incorrect. This can result from the population member providing not correct answers due to language understanding, bias view or lack of data about the subject.

The multimodal approach in the question design help reduce broader misunderstanding of the questions and reduced biases in the data.

\subsubsection{Coding Error or Recording Error}

With this type of error, correct data are obtained, but errors are made in coding or recording the data. In this survey we used quality control and edit procedures throughout the survey process to reduce errors made by data entry personnel. 


\subsubsection{Non-Coverage Error}

This occurs when members of the population are missing because they were not included in the list from which the sample was selected. These population members were not part of the list because they could not be located or were not known to exist. The sampling frame included about 95 percent of all principals that are deemed stakeholders with regards to the B \& R; the remaining 5 percent represent non-coverage error. To the extent those principals missing from the frame are different from those included, a small bias could have been introduced into the study. Non-coverage of five percent is deemed acceptable in most surveys.

\subsubsection{Non-Response}

Non-response occurs when people who are selected to participate in a research study fail to respond to the survey. Non-response results when an intended respondent cannot be contacted or, though contacted, refuses to participate. If there is a systematic difference between those who responded and those who did not respond to the survey, then the survey results are subject to non-response bias. Non-response increases the variability of survey results, due to the decrease in the effective sample size, and may cause bias if the non-respondents and respondents differ with respect to the characteristic of interest.

\section{Data Analysis and Findings}

\section{Analysis of Respondent Answers}

The survey answers below reflect an interesting view from a different pool of respondents.

- Most of the respondents come from China, with International Relations studies and diplomats located in Beijing (Table 1, Table 2).

- $92 \%$ of respondents acknowledging their knowledge of the B \& $\mathrm{R}$ initiative reflects its positive public relations image and reaches the global level. And $100 \%$ of the interviewees have faith in its importance in bringing economic development to all nations involved (Table 3 ).

- The expectations when it comes to the B \& $\mathrm{R}$ is to play a role in Infrastructure build-up and trade (Table 4, Figure 7).

- The initiative helped African nations to develop as well as south Asian ones. However, we also notice that the B \& R needs to address equity and equal support to all stakeholders from the survey. And it should go beyond money transfer (Figures 8-10).

- Challenges represent themselves in the form of the broad coverage of the project, the usage of the infrastructure built, supporting the real economy, debt issues, and trust of all stakeholders on the project.

Expectations related to the B \& R initiative Figure 7.

The belt and road initiative contributions (Figure 8 \& Figure 9).

Main Challenges of the belt and road initiative (Figure 10). 


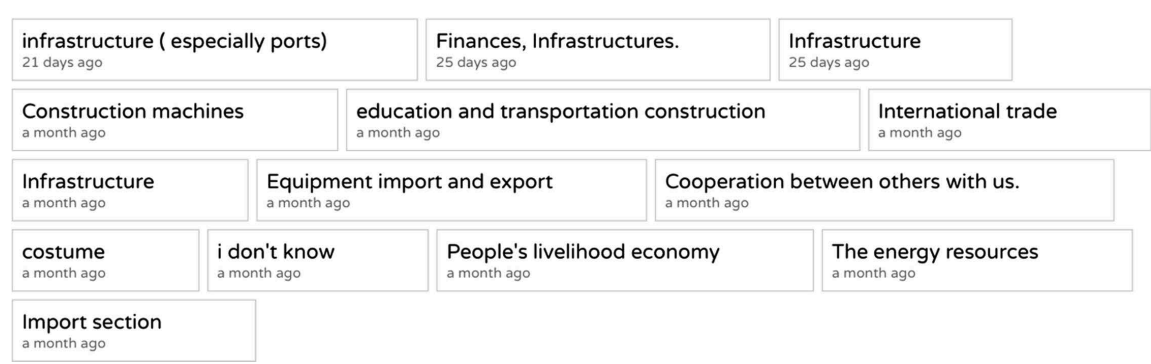

Figure 7. B \& R initiative's focus part of the economy.

It has contributed and will contribute to increasing job opportunities in a number of African countries. It helped bring people closer together and the Chinese.

1 days ag

develop infrastructures.

Not sure. For africa, not sont much impact

infrastructure construction

25 days ag 25 days ago

transportation ad telecom construction from belt and road projects help Afrecan countries with basic foundation for economic developement a month ago

Under the Belt and Road Belt and Road framework, the railways and highways under construction will maximize the level of trade within the African region, expand the import and export scale of African countries, and promote the integration of African economies into the global economy.

a month ag

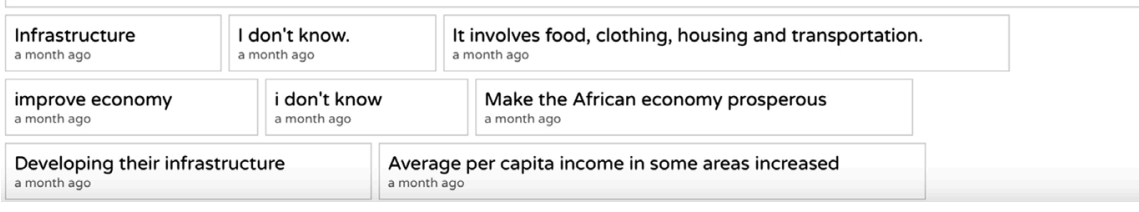

Figure 8. The belt and road initiative contributions I.

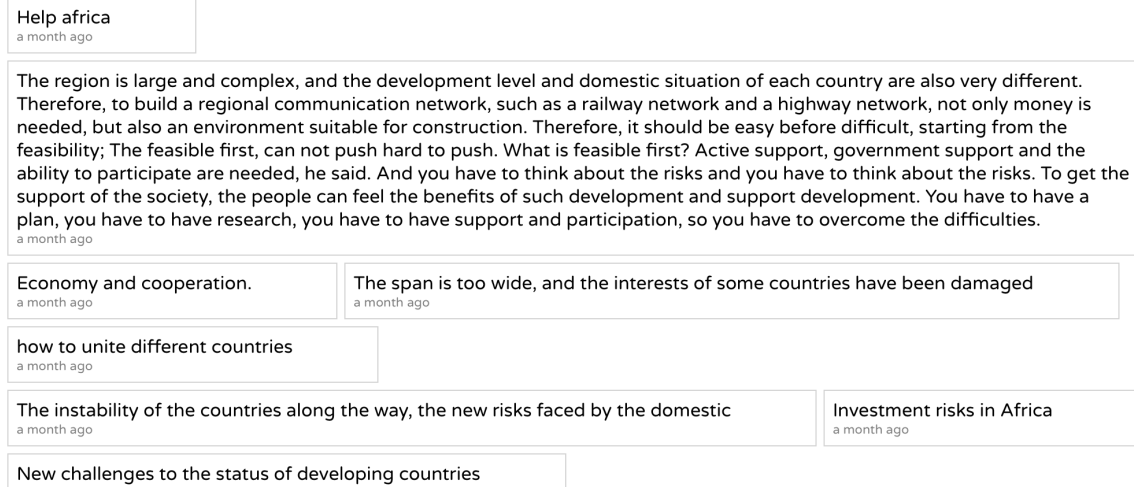

The region is large and complex, and the development level and domestic situation of each country are also very different. Therefore, to build a regional communication network, such as a railway network and a highway network, not only money is Therefore, to build a regional communication network, such as a railway network and a highway network, not only money is
needed, but also an environment suitable for construction. Therefore, it should be easy before difficult, starting from the needed, but also an environment suitable for construction. Therefore, it should be easy before difficult, starting from the
feasibility; The feasible first, can not push hard to push. What is feasible first? Active support, government support and the feasibility; The feasible first, can not push hard to push. What is feasible first? Active support, government support and the
ability to participate are needed, he said. And you have to think about the risks and you have to think about the risks. To get the support of the society, the people can feel the benefits of such development and support development. You have to have a plan, you have to have research, you have to have support and participation, so you have to overcome the difficulties. \begin{tabular}{l|l}
\hline $\begin{array}{l}\text { Economy and cooperation. } \\
\text { a month ago }\end{array}$ & $\begin{array}{l}\text { The span is too wide, and the interests of some countries have been damaged } \\
\text { a month ago }\end{array}$
\end{tabular} how to unite different countries a month ago

The instability of the countries along the way, the new risks faced by the domestic month ago

New challenges to the status of developing countries month ago

Figure 9. The belt and road initiative contributions II.

Table 3. Knowledge of the B \& R initiative.

\begin{tabular}{cc}
\hline Knowledgeable of the B \& R Initiative & Percentage \\
\hline Yes & $93 \%$ \\
No & $7 \%$ \\
\hline
\end{tabular}

Table 4. Positive expectation on B \& R initiative.

\begin{tabular}{cc}
\hline Positive Expectation on B \& R Initiative & Percentage \\
\hline Yes & $100 \%$ \\
No & $0 \%$ \\
\hline
\end{tabular}




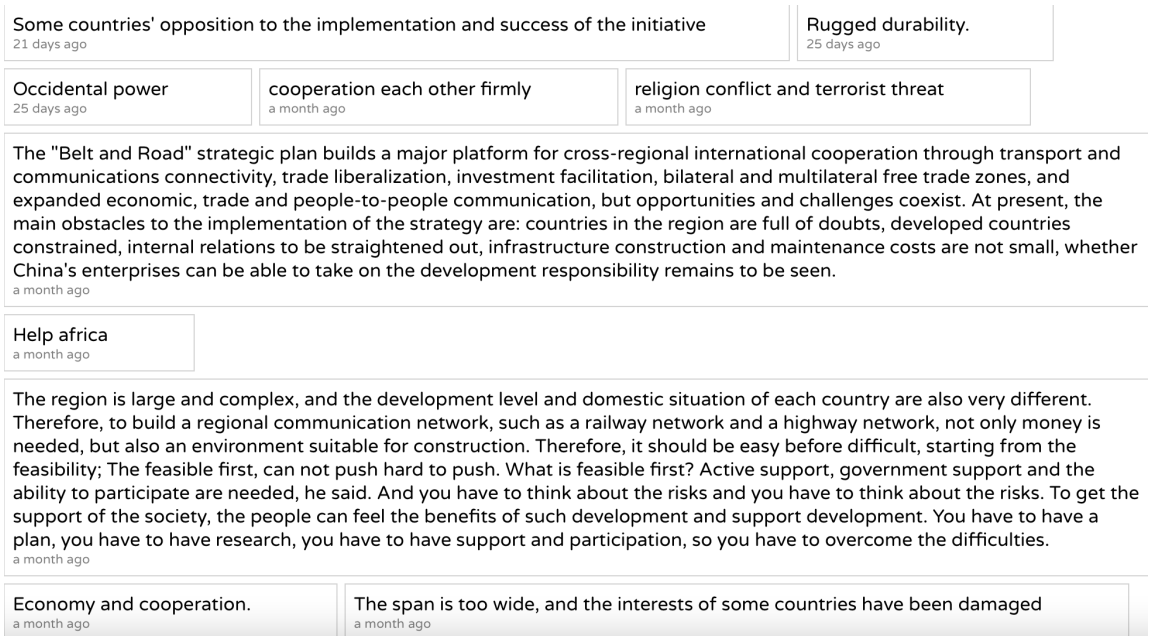

Figure 10. Main challenges of belt and road initiative.

\section{Discussions and Conclusion}

\section{1) Discussions and Conclusion}

This research aimed to study the impact of the initiative with examples in South Asia and Africa, especially in Kenya, focusing on the local economy.

The $\mathrm{B} \& \mathrm{R}$ initiative has proven to be a key economic initiative with a domestic impact and an international one. The $\mathrm{B} \& \mathrm{R}$ has ignited a new economic momentum for undeveloped economies eager to have access to funds and knowhow in Infrastructure building, highways, airports, seaports, railway linkages, and energy development have an impact on the social and local economic fabrics of the host nations. Without infrastructure, domestic growth and economic expansion cannot happen. The premise is simple, to move goods, there should be infrastructure.

The Infrastructure build-up has to go beyond the physical-economic assets of transportation nodes to include logistics capacity, warehousing space, and financial facilitation in the form of Micro-Loans. The cyber-economic space also is as important as the brick-and-mortar goods need to find markets through e-commerce platforms and phone banking solutions.

\section{2) Recommendations}

The OBOR initiative is a new strategy developed by China to promote economic integration internally and internationally in regional and global cooperation.

Given its comprehensive geographical coverage and economic scope, this paper aims to evaluate the impacts of one belt one road in Africa and South Asia. It has been proven that Africa and Kenya and examples are considered the hub of Africa's initiative. China participates in the development of Kenya and its regional economic powerhouses.

The data and survey results all point to the initial success of the $\mathrm{B} \& \mathrm{R}$ initiative. Now the question is, what is the next step ahead? As the COVID-19 has halted the world economic flow, the future is still undecided on how China will 
pursue its globalization through the Belt and Road while strengthening its domestic GDP to overcome the global economic turndown.

\section{3) Suggestion for Further Research}

As China has in 2020 put a new emphasis on a double circulation strategy that focuses on growing its local market while keeping China engaged internationally through the supply chain value, it is interesting to see how the $B \& \mathrm{R}$ will move forward? What are the new trends, and how the B \& R initiative can go beyond boiling infrastructure to develop local economies?

\section{Conflicts of Interest}

The author declares no conflicts of interest regarding the publication of this paper.

\section{References}

(2017). Full Text of President Xi's Speech at Opening of Belt and Road Forum-Xinhua. Xinhua Net. http://www.xinhuanet.com/english/2017-05/14/c 136282982.htm

(2018). Capital on the Road: Belt and Road Boosts Yuan Worldwide. CGTN. https://news.cgtn.com/news/3d3d774d7851444f79457a6333566d54/index.html

(2018). China's One Belt and One Road Initiative (OBOR). https://taxation88.blogspot.com/2018/10/chinas-one-belt-and-one-road-initiative.html

(2019). Belt \& Road Initiative (BRI). Ou Jian Network. https://www.oujiangroup.com/news/belt-road-initiativebri

(2019). The Belt and Road Initiative: From China, for the World. China Plus. http://chinaplus.cri.cn/news/politics/11/20190422/279204.html

(2020). What Is Belt and Road Initiative? Xinhua Silk Road-Belt and Road Portal, China's Silk Road Economic Belt and 21st Century Maritime Silk Road Website. https://en.imsilkroad.com/p/310470.html

(n.d.). Financing Operations. Beijing: Asian Infrastructure Investment Bank. https://www.aiib.org/en/about-aiib/who-we-are/financing-operations/index.html

(n.d.). List of Belt \& Road Member Countries. Belt and Road News. https://www.beltandroad.news/list-of-belt-road-member-countries

Alkhalloufi, T. (2017). The Chinese Dream of the Belt and Road Initiative. Global Times. https://www.globaltimes.cn/content/1042120.shtml

Alkhalloufi, T. (2019). BRI Creates a New Asian Paradigm for Global Economic Integration and Inclusiveness. Global Times. https://www.globaltimes.cn/content/1146030.shtml

Cheng, L. (2016). Three Questions on China's "Belt and Road Initiative". China Economic Review, 40, 309-313. https://doi.org/10.1016/j.chieco.2016.07.008

Du, M. M. (2016). China's “One Belt, One Road” Initiative: Context, Focus, Institutions, and Implications. The Chinese Journal of Global Governance, 2, 30-43. https://doi.org/10.1163/23525207-12340014

Godement, F. (2015). One Belt, One Road: China's Great Leap Outward (p. 2). London: China Analysis, European Council on Foreign Relations.

Kratz, A. (2015). Paying the China Price: The Costs of Chinese Investment (p. 108). London: European Council on Foreign Relations. 
Lagarde, C. (2019). Belt and Road Initiative: Two Key Channels to Achieving Financial Connectivity. Washington DC: International Monetary Fund.

https://www.imf.org/en/News/Articles/2019/04/24/sp042519-belt-and-road-initiative-t wo-key-channels-to-achieving-financial-connectivity

Lim, C., \& Mack, V. (2018). The Four Challenges of the Belt and Road. China US Focus. https://www.chinausfocus.com/finance-economy/the-four-challenges-of-the-belt-and-r oad

Marcel, D. T. A. (2018). The Impact of China's One Belt One Road Initiative in Africa: The Evidence from Kenya. Munich Personal RePEc Archive, 1-9. https://mpra.ub.uni-muenchen.de/90460

Nabar, M. \& Tovar, E. C. (2017). Renminbi Internationalization. In R. W. Lam, M. Rodlauer, \& A. Schipke (Eds.), Modernizing China-Investing in Soft Infrastructure (pp. 249-277). Washington DC: International Monetary Fund.

Perkins, P. (2016). The Role of Economic Infrastructure in Economic Growth: Building on Experience. 24-25.

Phillip, J. (2020). China's Belt and Road Initiative. Tacoma, WA: The Borgen Project. https://borgenproject.org/chinas-belt-and-road-initiative

Ponomarenko, L., Sidorov, D., \& Zabella, A. (2017). China’s “One Belt One Road” Initiative. Advances in Social Science, Education and Humanities Research, 124, 1100-1103.

PwC's Growth Markets Centre (2016). China's New Silk Route: The Long and Winding Road. PwC.

https://www.pwc.com/gx/en/growth-markets-center/assets/pdf/china-new-silk-route.p df

Saki, M. A. (2018). Belt and Road Initiative: Contribution by All, Benefits for All. https://en.mehrnews.com/news/139514/Belt-and-Road-Initiative-Contribution-by-allbenefits-for-all

Seth, S. (2020). Understanding One Belt One Road (OBOR). Investopedia. https://www.investopedia.com/terms/o/one-belt-one-road-obor.asp

Seth, S. (2021). Understanding One Belt One Road (OBOR). Investopedia. https://www.investopedia.com/terms/o/one-belt-one-road-obor.asp

Shepard, W. (2017). The Real Role of the AIIB in China's New Silk Road. Forbes. https://www.forbes.com/sites/wadeshepard/2017/07/15/the-real-role-of-the-aiib-in-chi nas-new-silk-road/?sh=2801684c7472

Sinha, A. (2020). Africa and the Chinese Debt Trap. MyVoice. https://myvoice.opindia.com/2020/06/africa-and-the-chinese-debt-trap

Srinivasu, B., \& P, S. R. (2013). Infrastructure Development and Economic Growth: Prospects and Perspective. Journal of Business Management \& Social Sciences Research (JBM\&SSR), 1.

World Bank (2016). https://openknowledge.worldbank.org/handle/10986/23285? show=full

Yu, H. (2016). Motivation behind China's “One Belt, One Road” Initiatives and Establishment of the Asian Infrastructure Investment Bank.

Zhao, M. H. (2016). The Belt and Road Initiative and Its Implications for China-Europe Relations. The International Spectator, 51, 1-10.

https://doi.org/10.1080/03932729.2016.1235819 


\section{List of Abbreviations}

$\begin{array}{ll}\text { Abbreviations } & \text { Meaning } \\ \text { B \& R } & \text { Belt and Road Initiative } \\ \text { IMF } & \text { International Monetary Fund } \\ \text { AIIB } & \text { Asian Investment and Infrastructure Bank } \\ \text { FDI } & \text { Foreign Direct Investment } \\ \text { EBRD } & \text { European Bank for Reconstruction and Development } \\ \text { EIB } & \text { The European Investment Bank } \\ \text { ADB } & \text { The Asian Development Bank }\end{array}$

